Magyar Honvédség Egészségügyi Központ

\title{
Tömeges sérültellátás aspektusai és lehetőségei a lőtt és robbantásos merényletek esetén
}

\section{Opauszki Judit}

Kulcsszavak: katasztrófa-egészségügy, lött-robbantásos sérültek, merényletek, iszlamista terrorizmus, tömeges sérültellátási gyakorlat, felkészültség javitása, tourniquet

\begin{abstract}
Magyarországon - mint ahogyan napjainkban a világ számos országában is - számolni kell a terrorizmussal. A terroristák, különösképp az ámokfutó és öngyilkos merénylök, a lőfegyverrel elkövetett támadást és a bombamerényleteket részesítik előnyben. A terrortámadásoknak betudható összes haláleset több, mint 70 százalékát löfegyverek és pokolgépes merényletek okozták, és ezek teszik ki a merényletekben megsebesültek mintegy 65 százalékát is. A véletlenszerüen kiválasztott katonák, illetve mentőtisztek, mentőápolók katasztrófa-egészségügyi ismereteinek felmérése és annak értékelése során arra a felismerésre jutott a szerzö, hogy a lött és robbantott sérültek ellátásának gyakorlása alig szerepel felkészítésükben, kiképzésükben. Ezen a harctéri tapasztalatok átvételével, illetve rendszeres gyakorlatokkal lehetséges változtatni.
\end{abstract}

Különböző közúti terelőelemeket korábban leginkább csak útépítéseknél láthattunk, az utóbbi években azonban karácsonyi vásárok, futóversenyek, tömegrendezvények már-már megszokott kísérőivé váltak. Ez azonban már következmény. Míg egyfelől a terelőelem a biztonságérzet csalóka tudatát nyújtja - elvégre csak és kizárólag a tömegbe hajtó, gázoló merénylők ellen nyújthat védelmet - a fegyveres, pokolgépes támadók esetében nem hatékony -, másfelől viszont azt üzeni, hogy a támadás akár itt is megtörténhet. Mert mindenhol megtörténhet, és senki nem érezheti magát biztonságban, ha nem is mindig hangsú- lyosan, de mindenképp életünk állandó részévé vált a terrorizmus. És valószínüleg ez is lehetett a terroristák célja.

Mindezt példátlan, sokkoló képsorok elözték meg. 2004 óta egyedül Európát, legalább tíz ember halálát okozó, iszlamista terrorszervezethez köthető merénylet érte. Spanyolországban kettő, az Egyesült Királyságban három, Franciaországban három, Németországban és Belgiumban egy-egy. A támadásokban összesen 597-en haltak meg, ami önmagában sokkoló adat [18].

A terrorizmus korábban is létezett, de megtanultuk, hogy jól körülhatárolható helyekre korlátozódik, afféle helyi 
sajátosság gyanánt, az IRA és az ETA nem robbantott például Olaszországban. A merényleteket emiatt - némi lelkiismeret-furdalással - leválaszthattuk az életünkröl. Sosem itt, hanem ott, odaát, a távolban történtek ezek a szörnyüségek, elkerülésükhöz pedig mindössze elég volt annyi, hogy nem utaztunk oda.

Mint a szakirodalom megjegyzi, a sajtó és a közösségi oldalak közvetítésével egyértelművé vált az átlagemberek számára a változás: a történelemkönyvben tanultaktól eltérően ezúttal nem egy jól körülhatárolható ország hadserege támadott meg egy másik országot, hanem egy adott esetben több országban is illegálisan jelenlévő sejtekből álló terrorszervezet támadott meg védtelen embereket. A terroristák figyelmeztetés nélkül vagy csak minimális figyelmeztetést követően csapnak le. Rejtett fegyverekkel és gyakran öngyilkos merénylőkkel hajtják végre, amivel a védtelen lakosság körében a legnagyobb csapást képesek okozni. A jelenlegi kiszámíthatatlanság azonban jelentős sérülékenységgel - és annak tudatával párosul a modern életforma és igények következtében. A szeptember 11-i terrortámadásokat követően világszerte megváltozott az emberek katasztrófákkal kapcsolatos hozzáállása. Az „ez nem történhet meg velünk" kijelentést másik váltotta: „Ez velünk is megtörténhet." A látványos, kis valószínüséggel bekövetkező, ám súlyos következményekkel járó esetek, amikről a sajtó széles körben beszámol, gyanakvóvá tették a lakosságot [3].

A sérthetetlenség, sebezhetetlenség illúziójának elvesztésénél csak a látvány volt sokkolóbb. Míg régen csak távoli természeti jelenségek, hazai balesetek látványa borzasztotta $\mathrm{az}$ átlagos tévénézőt, a potenciális célponttá válással a terror közel került, amiről gyorsan megtanultuk, hogy egy pillanat alatt csatatérré vagy másképp fogalmazva harctérré változtat mindent.

A harctér kifejezés szó szerint értelmezendő. Az Európát sújtó, számos emberéletet követelő merényleteknél túlnyomó részében lőfegyvert, illetve bombákat, pokolgépeket alkalmaztak. Ebből kifolyólag a sérülések jellege is túlnyomó részt harctéri körülményekre emlékeztet. Lőtt-robbantott sérülteket kell tömegével a helyszínre érkező mentőegységeknek ellátniuk. De vajon megfelelően felkészültek Magyarországon erre a feladatra? A cikk végén ismertetett - nem reprezentatív - kutatásomból az derül ki, hogy mégtöbb tömeges sérültellátási gyakorlatra lenne szükség.

Magyarországon a tömeges baleset viszonylag gyakori, a katasztrófa-fenyegetettség alacsony, de bizonyos típusú katasztrófákra számítani kell, ezek közé tartoznak a terrorcselekmények is. A felkészülés elengedhetetlen („expect the unexpected!"), hiszen a helyszíni szervezési intézkedések meghatározóak [7].

Hazai forrásból azonban elég peszszimista képet kapunk erről. "Sajnos hazánkban egyetlen mentésre jogosult szervezet sem rendelkezik önállóan olyan erő és eszközkészlettel, hogy egy terrorcselekmény következményeinek felszámolására irányuló komplex mentést önállóan képes legyen végrehajtani. Szükség lenne egy terrorelháritó egység felállitására, de ehhez hazánkban a feltételek nem adottak. (...) A megoldás az összefogásban rejlik. Meg kell ismerni az összes szervezet különleges képességeit, ki kell dolgozni a taktikai lépéseket, és gyakorlatokat kell szervezni az érintett állományok részére" [10].

\section{Robbantásos merényletek}

A terroristák eszköztára végtelen, kezdve az öngyilkos merénylőkön, hagyományos robbanószereken és katonai fegy- 
vereken át a tömegpusztító (nukleáris, biológiai vagy vegyi) fegyverekig.

Robbantásos terroristamerényletek okozzák leggyakrabban a tömeges sérülésekkel járó eseteket, ehhez az elkövetők általában kevés robbanóanyagot alkalmaznak. Ugyanakkor, amikor épületekben, csővezetékekben vagy mozgó jármüvekben helyezik el, használatuk sokkal súlyosabb következményekkel is járhat. Ilyenkor az áldozatok nagy számáért nem csak a robbanás intenzitása okolható. A szerkezeti sérülések folytán összeomló épületek még tovább növelik az áldozatok számát. Nagyobb fenyegetést jelent a hagyományos robbanószerek kombinálása vegyi, biológiai vagy sugárzó anyaggal, mint amilyen a "piszkos bomba” (dirty bomb), ez hagyományos robbanóanyagot elegyít radioaktívval [16].

Öngyilkos merénylet esetén a terrorista általában robbanóövet vagy mellényt visel a testén, vagy egy aktatáskában, sporttáskában, hátizsákban viszi, ami általában TNT-t, vagy házilag készített robbanóanyagokat tartalmaz, apró vasdarabokkal, rengeteg szöggel körbevéve. A másik lehetőség, hogy az öngyilkos merénylő több tonna robbanóanyaggal megrakott teherautót vezet a kiválasztott cél felé. Az öngyilkos merénylők egyre inkább összedolgoznak, így a terrortámadás helyszínére érkező első ellátók egy további robbantás célpontjává válhatnak. A terroristák által leggyakrabban alkalmazott robbanóeszköz házilag készül. A robbanóanyagot általában valószínütlennek tünő helyen rejtik el. Ez lényegében bármi lehet: dinnye, kukta, fémcső, állati tetem, üreges kő, borosüveg, hátizsák vagy emberi holttest. A szerkezetet felszerelhetik infravörös érzékelővel, ami akkor élesíti az eszközt, amikor valaki a bomba közelébe ér. A robbantás általában távirányítással történik. A szerkezetben elrejtett robbanóanyag mennyiségének és a célterület jellegzetességeinek függvényében az áldozatok száma pár fötól a tucatnyiig terjedhet [3].

Noha a terroristák egy sor készen hozzáférhető fegyvert használnak, a merényletek során továbbra is kitartanak a robbanószerkezetek alkalmazása mellett nagy károkozó képességük és szimbolikus jelentőségük miatt. 2016-ban a konfliktusos zónákból illegálisan terjedni kezdtek a bombakészítéssel kapcsolatos ismeretek, instrukciók. A szükséges hozzávalók hozzáférhetősége ösztönözte a házi készítésű robbanóeszközök (IED, improvised explosive device) használatát. Különös aggodalomra ad okot a kevéssé védett célpontok ellen házilag gyártott robbanószerkezetek révén elkövetett támadások, illetve az öngyilkos merénylő által viselt házilag gyártott robbanóeszközök alkalmazása.

$\mathrm{Az}$ iszlamista terroristák házilag készített robbanóeszközzel végrehajtott támadásai általában kevéssé védett célpontok ellen irányulnak, és leginkább tömeges sérülést kívánnak okozni a civil lakosság körében. Az utóbbi években a célpontok közé került a légiközlekedés, a vasút, a kereskedelem és a jelentős sportesemények helyszínei is.

Az EU-ban alkalmazott házilag gyártott robbanóeszközök használatát illetöen két irányvonal különböztethetö meg. Kivitelezésükben és felépítésükben hasonlóságot mutatnak a konfliktusövezetekben használt eszközökkel. Utóbbiak egyes elemeit módosíthatták az EU-ban rendelkezésre álló erőforrások és körülmények miatt. Például a házilag gyártott robbanószerekkel és rögtönzött alkatrészekkel helyettesítették a nehezen beszerezhető katonai alkatrészeket. Ilyen szerkezetek gyakoribbak terroristacsoportok, valamint az Iszlám Állam irányí- 
totta magányos szereplők által elkövetett támadások esetében. A közös bennük, hogy logisztikai háttérre és speciális ismeretekre van szükség nagyobb menynyiségű robbanószer házi előállítása során. Ugyanakkor az így készült robbanószerkezetek nem különösebben kifinomultak, viszont eléggé megbízhatóak, használatuk pedig egyszerü.

Jóval egyszerübb robbanóeszközöket használnak mostanában az iszlamista terroristák. Ezek többségében készen hozzáférhető összetevőkből állnak, ilyen például a gázpalack, pirotechnikai, illetve ammóniumnitrát alapú termékek. A felsorolt alkatrészekből, összetevőkből álló robbanóeszközöket minden különösebb szaktudás, felkészülés, tervezőmunka vagy logisztikai háttér nélkül meg lehet építeni. Ezeket elsődlegesen kisebb terrorista csoportok vagy az Iszlám Állammal rokonszenvező magányos terroristák alkalmazzák. Figyelemreméltó, hogy az Iszlám Állam a készen hozzáférhető gyúlékony anyagok használatát javasolja egyszerü, házi gyújtóbombák elkészítéséhez, gyújtogatásos merényletekhez magányos elkövetők részére.
Létezik a polgári légiközlekedés ellen házilag készített robbanóeszközök révén végrehajtott támadás veszélye is. A legnagyobb veszélyt a rejtett és nehezen észlelhető házilag gyártott robbanóeszközök használata jelenti, illetve az, hogy repülötéri alkalmazottként dolgozó segítöik révén akár elkerülhetővé válhat a biztonsági átvizsgálás, ellenőrzés.

Nemcsak az iszlamista terroristák jelentenek veszélyt. Szélsőjobboldali, baloldali és anarchista csoportok és egyének körében továbbra is népszerüek a fegyverek, robbanószerek [4].

\section{Terrorizmus Európában és az EU-ban}

Az alábbiakban kizárólag a 2014 óta löfegyverrel, pokolgéppel elkövetett iszlamista támadásokat foglaltam össze az I. táblázatban (az adatok nem tartalmazzák az elkövetőket). Külön gyüjtöttem a gépjárművel elkövetett terrorcselekményeket. Mindezeken kívül - föleg 2017-ben - gyakoriak voltak a késelések, ezeket azonban az összesítés nem tartalmazza, hiszen az áldozatok száma nem közelíti meg az előbbieket (I. táblázat).

I. táblázat. Iszlamista terrorizmus Európában 2014-től napjainkig (https://en.wikipedia.org/wiki/Islamic_terrorism_in_Europe_(2014\%E2\%80\%93present)

\begin{tabular}{|l|c|c|}
\hline A merénylet helyszíne, elkövetésének módja, idöpontja & Halott & Sérült \\
\hline $\begin{array}{l}\text { 2014. májusában egy, korábban a szír polgárháborúban az iszlamisták } \\
\text { oldalán harcoló férfi tüzet nyitott Brüsszelben }\end{array}$ & 4 & \\
\hline $\begin{array}{l}\text { 2015. januárjában fóként Párizsban végrehajtott terrortámadások során } \\
\text { a három merénylő négy fegyveres akciót hajtott végre }\end{array}$ & 17 & 22 \\
\hline $\begin{array}{l}\text { Novemberben Párizs központját érintette az a merényletsorozat, } \\
\text { amikor 35 perc leforgása alatt hat helyszínen összehangolt támadá- } \\
\text { sokra került sor. Lőfegyverrel és bombával végrehajtott merénylet a } \\
\text { Bataclanban. Emellett Saint-Denisben robbantásos merénylet volt a } \\
\text { Stade de France stadionon kívül egy francia-német meccs ideje alatt }\end{array}$ & 130 & 413 \\
\hline $\begin{array}{l}\text { Augusztusban egy férfi a Thalys nagysebességủ vonaton Amszterdam } \\
\text { és Párizs között fegyverrel fenyegette az utasokat }\end{array}$ & 3 \\
\hline
\end{tabular}




\begin{tabular}{|c|c|c|}
\hline A merénylet helyszíne, elkövetésének módja, időpontja & Halott & Sérüilt \\
\hline $\begin{array}{l}\text { 2016. januárjában Isztambulban egy öngyilkos merénylő felrobbantotta } \\
\text { magát }\end{array}$ & 13 & 9 \\
\hline Márciusban újabb pokolgépes öngyilkos merénylet Isztambulban & 4 & 36 \\
\hline $\begin{array}{l}\text { Márciusban Belgiumban három összehangolt öngyilkos, robbantásos } \\
\text { merényletet hajtottak végre terroristák: kettőt a brüsszeli repülötéren, } \\
\text { egyet pedig a metróállomáson }\end{array}$ & 32 & 340 \\
\hline $\begin{array}{l}\text { Júniusban Isztambulban automata lőfegyverekkel és robbanóövvel fel- } \\
\text { szerelt merénylők intéztek támadást }\end{array}$ & 45 & 230 \\
\hline $\begin{array}{l}\text { Júliusban egy németországi borozóban bombát robbantott egy mene- } \\
\text { kült }\end{array}$ & & 15 \\
\hline $\begin{array}{l}\text { Augusztusban két férfi Moszkva közelében felfegyverkezve egy rendőr- } \\
\text { őrsre támadt }\end{array}$ & 1 & 1 \\
\hline 2017. januárjában egy merénylő szintén Isztambulban a tömegbe lött & 39 & 70 \\
\hline $\begin{array}{l}\text { Áprilisban egy öngyilkos merénylő robbantotta fel magát a szentpéter- } \\
\text { vári metrón }\end{array}$ & 15 & 64 \\
\hline Áprilisban lőfegyverrel végrehajtott támadás Párizsban & 1 & 3 \\
\hline $\begin{array}{l}\text { Májusban öngyilkos bombamerénylet történt Manchesterben egy kon- } \\
\text { certet követően }\end{array}$ & 22 & 512 \\
\hline Augusztusban Párizsban egy autó mintegy tucatnyi katona közé hajtott & & 6 \\
\hline $\begin{array}{l}\text { Szeptemberben egy TATP-t tartalmazó bomba robbant fel egy londoni } \\
\text { metrómegállóban }\end{array}$ & & 30 \\
\hline $\begin{array}{l}\text { 2018. májusában Liège-ben egy merénylő késelést követően két rendőrt } \\
\text { és egy civilt lőtt le }\end{array}$ & 3 & \\
\hline
\end{tabular}

Szükséges megemlíteni a gázolásos, lentős áldozattal jártak. Ezt a II. táblázat iszlamista terroristák által elkövetett me- tartalmazza. rényleteket is, amelyek Európában je-

II. táblázat. Iszlamista terrorizmus Európában 2014-től napjainkig (https://en.wikipedia.org/wiki/Islamic_terrorism_in_Europe_(2014\%E2\%80\%93present)

\begin{tabular}{|l|c|c|}
\hline A merénylet helyszíne, elkövetésének módja, időpontja & Halott & Sérült \\
\hline 2016. júliusában egy teherautó Nizzában a tömegbe hajtott & 86 & 458 \\
\hline $\begin{array}{l}\text { Decemberben egy berlini karácsonyi vásárba hajtott egy terrorista, aki } \\
\text { később egy rendőrre is rálőtt }\end{array}$ & 12 & 56 \\
\hline 2017. márciusában Londonban egy merénylő gyalogosok közé hajtott & 5 & 50 \\
\hline $\begin{array}{l}\text { Áprilisban Stockholmban egy terrorista teherautóval a gyalogosok közé } \\
\text { hajtott egy bevásárló utcában, majd egy áruházba csapódott }\end{array}$ & 5 & 14 \\
\hline $\begin{array}{l}\text { Júniusban egy furgonnal gyalogosok közé hajtottak Londonban, majd a } \\
\text { három merénylö késelésbe kezdett }\end{array}$ & 8 & 48 \\
\hline $\begin{array}{l}\text { Augusztusban egy furgon gyalogosok közé hajtott Barcelonában, majd } \\
\text { a két helyszínről elmenekülő terrorista egy járókelőt halálra késelt }\end{array}$ & 14 & 152 \\
\hline
\end{tabular}


Ha áttekintjük a 2014 óta Európában elkövetett iszlamista merényletek sérülési és mortalitási adatait, arra a következtetésre juthatunk, hogy a kiugróan magas számú áldozattal járó támadásokat többségében löfegyverrel, robbanószerkezettel hajtották végre.

Európában iszlamista merényletben 2014 óta összesen 475-en haltak meg, és 2604-en sérültek meg. Ebből a lött, robbantásos támadások számlájára 341 halott $(71,7 \%)$ és 1754 sérült $(67,3 \%)$ írható, illetve gázolásos merénylet 130 halálos áldozatot követelt (27,3\%), 778an sérültek meg (29,8\%). Ez mutatja, hogy az Európa ellen irányuló iszlamista támadások gerincét a lőtt, robbantásos merényletek adták.

2017-ben összesen 205 sikertelen, meghiúsított, illetve végrehajtott terrortámadásra került sor az EU tagállamaiban, ezek közül 33 iszlamista, 24 baloldali, 5 jobboldali, 137 szeparatista indíttatású volt. (A szeparatista merényletek közül 88 az Egyesült Királyságban, 42 Franciaországban és 7 Spanyolországban történt.)

$\mathrm{Az}$ iszlamista terrorizmushoz köthető sikertelen, meghiúsított, illetve végrehajtott merényletek száma 2016-hoz képest megduplázódott. Ugyanakkor a támadások kevesebb mint harmadát hajtották csak végre. Kilenc támadást az Iszlám Állam vállalt magára, további négy merénylet elkövetését pedig az Iszlám Államnak tulajdonították.

Összességében az Egyesült Királyságban és Franciaországban volt a legtöbb iszlamista merénylet, ugyancsak itt a legmagasabb a sikertelen és meghiúsított merényletek aránya. 2017-ben az iszlamista terrorizmus okozta a legtöbb sérülést az EU-ban, 62 halottat és 819 sérültet.

Az utóbbi években az iszlamista támadások száma növekvő tendenciát mutat, de a felkészülést és a végrehajtást tekintve kevésbé kifinomultak. Bár az Iszlám Állam szervezeti felépítésének gyengülésével csökkenhet a csoport vonzereje, az Al-Kaida továbbra is nagy befolyással rendelkezik, és aktívan bátorít az EU területén végrehajtott terrorista támadások elkövetésére. A közeljövőben is valóságos veszélyforrás marad egy AlKaida vagy más iszlamista szervezet által elrendelt, irányított vagy ihletett terroristamerénylet [5].

Ennek megfelelően a lőtt-robbantásos merényletek tömeges sérültellátására való felkészülés különösen aktuális feladat marad, hiszen ez a leginkább elterjedt módszer a terroristák körében.

\section{Tömeges sérültellátás lött-robbantásos merénylet esetén}

Mivel a sérültek száma kezdetben meghaladja a rendelkezésre álló erőforrásokat, a helyszíni ellátás általában a szabad légút-biztosításra és a vérzéscsillapításra szorítkozik.

Csak akkor lehet további beavatkozásokra sort keríteni, amikor már elegendő erőforrás érkezett a helyszínre vagy megkezdődött a sérültek kórházba szállítása.

A robbanás okozta sérülési mechanizmus a következö öt tényezőn alapul:

- Elsődleges: a robbanás lökéshulláma miatti túlnyomásnak a szövetre gyakorolt közvetlen hatása. A levegő - a vízzel szemben - könnyen öszszenyomható. Ennek eredményeként a primer robbanásos sérülés szinte mindig a levegővel teli struktúrákat érinti, így a tüdőt, a hallószervet és az emésztőrendszert.

- Másodlagos: a robbanás következtében felszabaduló tárgyak (repeszhatás) okozta sérülések. 
- Harmadlagos: a test hely- és helyzetváltozásakor bekövetkező sérülések

- Negyedleges: a robbanás (robbanási gázok + lánghatás) okozta égési sérülések vagy a toxikus gázok, gőzök belégzése okozta légúti sérülés

- Ötödleges: a robbanás (robbanási gázok magas hőmérséklete) és lánghatás során felszabaduló vegyi, biológiai vagy radiológiai anyagok okozta kontamináció.

$\mathrm{Az}$ első tényező gyakorlatilag csak az üreges szerveket érinti, általában sérül a dobhártya. A tüdő gyakran sérül, pneumothorax és bevérzések fordulnak elő. Ez utóbbi légembóliát okozhat, ami bizonyos esetekben akár agyi történésre jellemző szimptómákat is mutathat (primer halálok). A bélrendszer sérülései a zúzódástól a kiterjedt szakadásig terjedhetnek. Mindig gondolni kell a tüdő érintettségére a robbanás áldozatainál [ 2 , 20].

Ilyen jellegű sérülésekkel a harctéri életmentő katonák, egészségügyi tisztek, altisztek gyakran találkozhatnak elsősorban békefenntartó missziókban. Sajnos hasonló mechanizmusú sérüléssel békeidőben is szembesülhetünk, például egy robbantásos terrorcselekmény következ- tében. A béke és minősített körülmények közt előforduló lőtt, robbantásos sérülések miatti halálozást az életfontosságú szervek roncsolódása, heves vérveszteség és annak következményeként kialakult sokk és légzési elégtelenség okozza [14].

Az ellátás módját a helyszín biztonsága, a sérültek száma, állapota és a mentésben résztvevők száma, kompetenciája és a rendelkezésre álló mentéstechnikai eszköz befolyásolhatja.

A Magyar Honvédségnél rendszeresített egészségügyi csomag (IFAK, Input First Aid Kit) tartalma (1. ábra):

- tourniquet (szorítókötés gyors felhelyezésére alkalmas, vérző végtagra 10-15 másodperc alatt rögzíthetö);

- izraeli kötszer vérzéscsillapító párnával, szorító-, fedö- és nyomókötésként is alkalmazható;

- orr-garat (naso-pharyngealis) tubus légút-biztosításhoz;

- gumikesztyü, ragtapasz [18].

A végtag súlyos vérzése esetén szorítókötés felhelyezése indokolt CAT-tel (Combat Application Tourniquet) vagy izraeli kötszerrel. A végtag felső harmadában egycsontos alapon a ruhára kell szorítani a vérzés megszűnéséig. Cson-

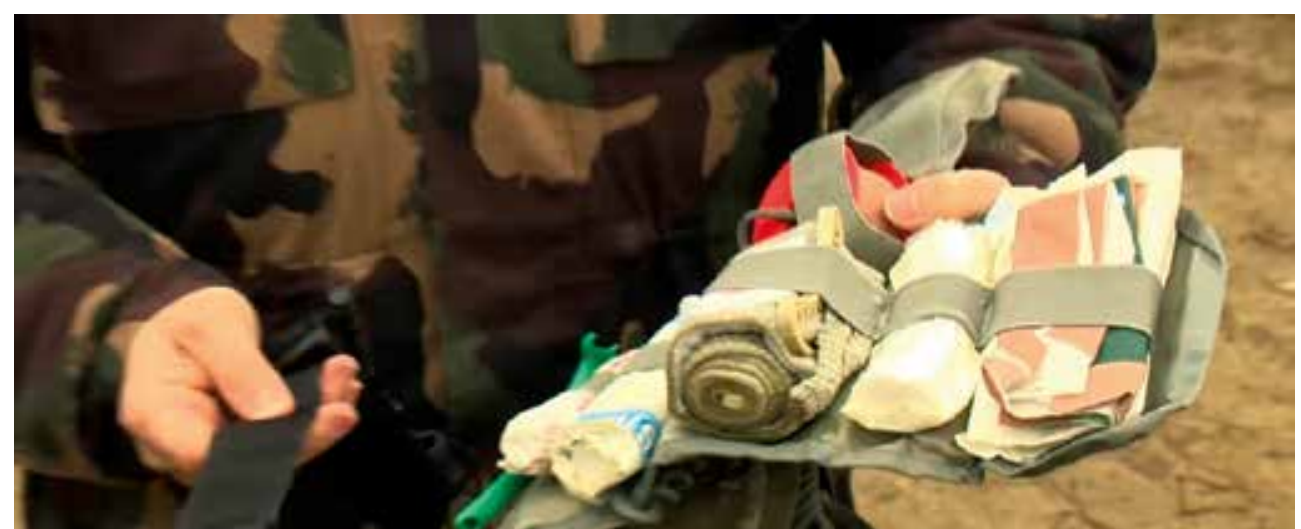

1. ábra. IFAK-csomag 
kolt sérülés esetén szintén egycsontos alapra kerül. A vérzés újraindulása esetén a meglévő szorítókötést meg kell szorítani, nyak- és hónaljvérzésnél csak nyomókötés felhelyezésére van lehetöség, erre a legmegfelelőbb az izraeli kötszer [11].

A robbantásos terrorcselekmények miatt rendkívüli módon felértékelődik a harctéri tapasztalat. A harctéri sérültellátás gyakorlatát kamatoztatni lehet a civil, tömeges sérültellátásban résztvevő mentőszolgálatok esetében is. Ennek jegyében alapvetően katonák körében elterjedt eszközök jelennek meg a civil mentés során, ilyen például a tourniquet [1].

Épp ezért a katasztrófahelyzetekben elvárható, a sérültek gyors kimentésére és helyszíni sürgősségi ellátásukhoz szükséges egészségügyi ismeretek begyakorlottságát mértük fel nem reprezentatív tesztelés során a civil mentötisztek, mentőápolók és a Magyar Honvédség állományába tartozó katonák (egészségügyi tisztek, altisztek) körében. Többek között azt vizsgáltuk, hogy szakképesítésük, illetve katona-egészségügyi kiképzésük idején a képzés során hány alkalommal gyakorolták az alábbi feladatokat, melyeket a katasztrófa-egészségügyi ismeretekhez tartozónak teszteltük: helyszíni betegosztályozás (triage); vérzéscsillapítás tourniquettel, lokális vérzéscsillapító szerekkel; vénabiztosítás, infúzió bekötése; tü-detenzionálás; gyógyszeres fájdalomcsillapítás; égett sérült ellátása; lőtt, robbantott sérült ellátása; sérült rögzítése lapáthordágyon; obszerválás eszköz nélkül, eszközzel transportig. A résztvevők 1-5-ig terjedő Likert-skálán jelölhették meg a válaszaikat, ahol a pontozás a következőképpen alakult: 1=soha; $2=1$ alkalommal; $3=2-5$ alkalommal; $4=6-10$ alkalommal; 5=10-nél több alkalommal gyakorolták az adott feladatokat.
A vizsgálat szempontjából kiemelendö, hogy a kutatásba bevont 49 mentőtiszt, mentőápoló katasztrófa-egészségügyi ismeretei megfelelőek, hiszen a felsorolt feladatok között nem szerepelt olyan, amelyet átlagosan legalább egyszer ne gyakoroltak volna szakképesítésük megszerzése során. A mentőtisztek, mentőápolók számára havonta, két havonta kötelező részt venni szakmai továbbképzésen, emiatt a kutatásba bevont katonaegészségügyben dolgozókhoz képest több tapasztalattal rendelkeznek, többet gyakorolták a felsorolt feladatokat. Ennek ellenére a lőtt, robbantásos sérülések ellátását gyakorolták a legkevésbé.

Ugyanakkor a vizsgálatba bevont mentőtisztek és mentőápolók jelentős része $(57,14 \%)$ részt vett már tömeges sérültellátási gyakorlaton.

A megkérdezett 69 katona esetében a kiképzés során való gyakorlás nem teszi lehetővé a megfelelő rutin megszerzését. Az eredmények alapján átlagosan soha vagy mindössze egyetlen alkalommal gyakorolták a felsorolt feladatokat kiképzéseik során (2. ábra).

Emellett azt is érdemes kiemelni, hogy ezek között több olyan feladat is előfordul, amelyet éles, harctéri helyzetben már gyakrabban kellene végezniük - különös tekintettel a lött, robbantásos sérülések ellátására - mégsem gyakorolták eléggé [13].

Mindazonáltal a Magyar Honvédség széleskörü feladatai miatt az elsősegélynyújtás és a harctéri elsősegélynyújtás készségszintű alkalmazása végzettségtől, rendfokozattól függetlenül minden katonára vonatkozik. A harctéri tapasztalatok alapján elmondható, hogy a hadmüveletek nélkülözhetetlen eleme az egészségügyi biztosítás, hiszen a sebesült katonáknál az első 10 perc a legkritikusabb a túlélés szempontjából. Szükség 


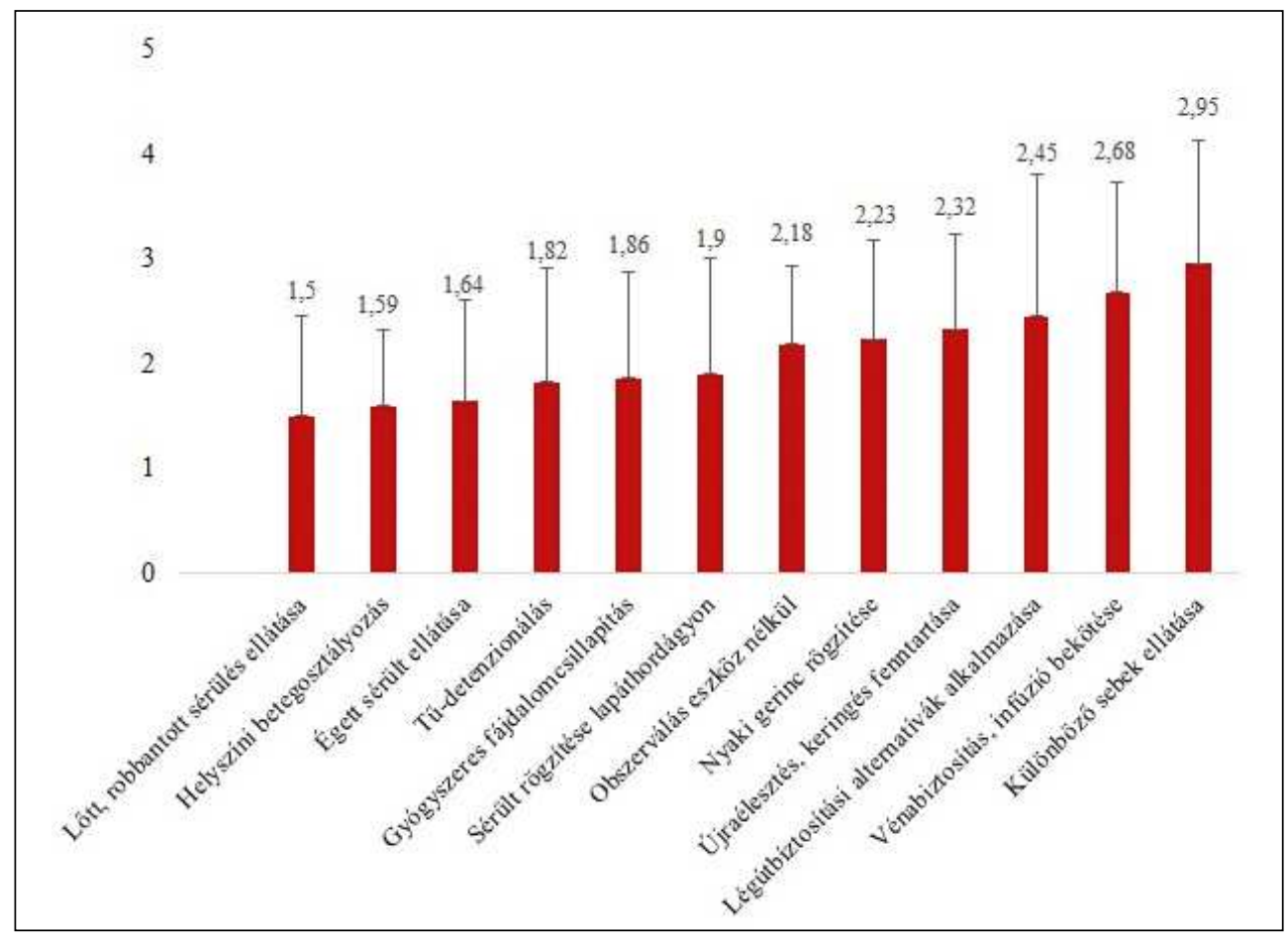

2. ábra. Katasztrófa-egészségügyi képességek gyakorlásának vizsgálata a Magyar Honvédség egészségügyi tisztjei és altisztjei körében

van tehát olyan katonákra, akik képesek a sérülések rövid időn belüli hatékony ellátására [17].

\section{Lőtt, robbantásos tömeges sérültellátás fejlesztési lehetőségei}

Az Országos Mentőszolgálat, a Katasztrófavédelem, a Magyar Honvédség, a Rendőrség és az egyéb műszaki mentőalakulatok közötti együttmüködés szükséges a hatékony fellépés érdekében. Ez az együttmüködés a napi rutin során is fontos, de nélkülözhetetlen a tömeges sérültellátás során [12].

Kétféle szimulációs gyakorlat terjedt el. A tantermi gyakorlat költséghatékony és nagyon hasznos módja a katasztrófaelhárítási képesség tesztelésének és értékelésének, hazánkban is ez terjedt el.
A gyakorlat kivitelezésének rendjét általában előre meghatározzák [12].

A tantermi gyakorlatok lehetővé teszik a valós idejű kommunikációt és interakciót számos különböző szolgálat között. Ezek a gyakorlatok tapasztalt vezető irányítását igénylik, aki végigvezeti a résztvevőket a feladatokon és kritikus szemmel értékeli a végén az eredményeket [16].

Ezzel szemben a terepgyakorlat nyúitja a leginkább valósághü felkészülést, ami kiterjed a katasztrófa-elhárítási tervben foglaltak megvalósítására is és az elözetesen leírt célok tényleges megvalósításának valós idejü kiértékelését teszi lehetővé.

Ideális esetben a gyakorlatok között szerepel a sebesülés helyszínéről való átszállítás a mentőszolgálat révén az egészségügyi intézményekbe. Ezek a gyakor- 
latok azonban munkaigényesek, hosszú ideig tartanak, és jelentős költségekkel járnak [12].

2018-ban egy hazai, „A fekvőbeteg-ellátó intézmények valós idejű kiürítésének ápolási ismeretei és feladatai" című kutatásban a szerzők javaslatokat fogalmaztak meg. Eszerint az alapképzések kerettantervében, felnőttképzési programjában, valamint a felsőfokú végzettségűek kimeneti képzési követelményrendszerében a tömeges sérültellátási, illetve katasztrófavédelmi ismereteknek kötelezően szerepelnie kellene. A képzésen túl - évente elméleti és gyakorlati jellegü ismétlő oktatásra lenne szükség [15].

A tömeges sérültellátási gyakorlatok azonban többségében megkoreografált, tervezett események, amelyek révén kevéssé lehet valós képet kapni a kórházak tényleges kapacitásáról: mennyire képesek előzetes bejelentés nélkül reagálni valós körülmények között. Az Egyesült Államokban több kórház által kidolgozott, elözetes bejelentés nélküli gyakorlat a kórház tömeges sérüléssel járó esemény bekövetkezését követő első 75 percben nyújtott intézkedéseire koncentrál. Az értékelés legfontosabb szempontja, hogy a gyakorlat teljes időtartama alatt menynyire képes a kórház fenntartani sürgősségi ellátó kapacitását az újonnan érkező sérültek azonnali triage-olása és ellátása érdekében [19].

Hasznos lehet a világhírü nemzetközi példák, pozitív gyakorlat tanulmányozása, mint amilyet az izraeli Galilee Medical Center (GMC) is kínál. A kórház komoly tapasztalatokra tett szert tömegsérüléses esetek terén. Ilyen volt a második libanoni háború 2006-ban, amikor 1820 sérült sürgősségi ellátására került sor egyetlen hónap leforgása alatt. 2011-ben egy teherautó hajtott a buszmegállóban várakozók közé, 29 súlyos sérülést okozva. 2013 áprilisa óta pedig folyamatosan látja el a szíriai háború sérültjeit, eddig több mint 1700 esetet.

A tömegsérüléssel járó esetekben több típust különböztet meg az intézmény:

- A) legfeljebb 20 sérült különböző súlyosságú sérülésekkel. Egyetlen kezelőhely kialakításával, kizárólag a kórházban tartózkodó személyzet bevonásával.

- B) több, mint 20 sérült, a teljes sürgősségi osztály kitelepülésével, a teljes kórházi személyzetet riasztásával. [6].

Összegzésként elmondható, hogy a szakirodalom alapján a terrorcselekmények bekövetkezésére Magyarországon is számítani kell. A terroristák - ezen belül is az iszlamista terroristák - elönyben részesítik a robbantásos támadásokat. (Valószínűleg nem véletlen, hogy a Magyar Honvédség Egészségügyi Központ az Országos Mentőszolgálattal közösen egy fôvárosi robbantásos merénylet sérült-ellátását gyakorolta 2017. november 7-én a Honvédkórházban. A gyakorlat szükségességét többek között az Európában állandósult nemzetközi terrorveszéllyel, a terrortámadásokkal indokolták) [9].

Ugyanakkor kijelenthetö, hogy a nem reprezentatív mintában szereplö helyszíni mentést végzők - civilek és katonák egyaránt - épp a lőtt, robbantásos sérültek ellátását gyakorolják a legkevésbé. További sajátosság, hogy a késeléses merényletekkel ellentétben a lőfegyverrel, robbantással elkövetett terrortámadások sok esetben tömeges sérüléssel (nem ritkán több, mint 50 sérült) is járnak. Ezekre az esetekre a harctéri tapasztalatok adaptálásával, szimulációs gyakorlatokkal szükséges még jobban felkészülni. 
A katona-egészségügyi, katasztrófaegészségügyi képzések fejlesztésére, a harctéri tapasztalatok, nemzetközi példák tanulmányozására, átvételére, rendszeres, valósághü tömeges sérültellátási gyakorlatokra van szükség annak érdekében, hogy a mentési munkálatokban az érintett szervezetek jól együttmüködhessenek, azonos felszereléseket használjanak, azonos felkészültséggel nézzenek szembe a tömeges sérültellátás jövőbeli kihívásaival, különösképp ideértve a lött, robbantásos sérültellátás eseteit [13].

\section{Irodalom}

[1] Borgers, G.: Brussels Terror Attacks on 22 March 2016: Cooperation between Military and Civilian Emergency services. 2016, Powerpoint előadás, MIMMS Course, Budapest

[2] Campbell, J. (2013). Helyszíni sérültellátás. Budapest: Medicina, Deák, P., 2005

[3] Edwards, F., Steinhäusler, F. (szerk.): NATO and terrorism. On scene: new challenges for first responders and civil protection. Ericeira: Springer, 2006

[4] Europol.: TE SAT European Union Terrorism Situation and Trend Report 2017. https:// www.europol.europa.eu/sites/default/files/ documents/tesat2017_0.pdf

[5] Europol.: TE SAT European Union Terrorism Situation and Trend Report, 2018. https:// www.europol.europa.eu/sites/default/files/ documents/tesat_2018_1.pdf

[6] Farraj, M., Barhoum, M.: Galilee Medical Center Mass Casualty Preparedness. 2017. [PowerPoint előadás, NATO MASCAL Course]

[7] Gőbl G., Gorove L.:Tömeges sérültellátás (tömeges baleseti ellátás). 2015, [Powerpoint előadás] Available from: https://docplayer. hu/42726683 - Tomeges-serultellatastomeges-baleseti-ellatas.html

[8] Kedden nagyszabású egészségügyi és sérültellátási gyakorlatot tartanak a Honvédkór- házban, 2017. https://honvedelem.hu/cikk/ 66106_kedden_nagyszabasu_egeszsegugyi_ es_serult-ellatasi_gyakorlatot_tartanak_a_ honvedkorhazban

[9] Kuti R., Kárfelszámolási müveletek lehetőségei terrorcselekmények esetén. https:// docplayer.hu/27505055-Karfelszamolasimuveletek-lehetosegei-terrorcselekmenyekeseten-bevezetes-a-beavatkozas-kiemeltkerdesei-kuti-rajmund-tuzolto-szazados.html

[10] Magyar Honvédség Egészségügyi Központ. Egészségügyi alapismeretek, elsősegélynyújtás a harctéri életmentő katonák részére. Budapest, 2013.

[11] Major L., Liptay L., Orgován Gy. (szerk.): A katasztrófa-felszámolás egészségügyi alapjai. Budapest, Semmelweis Kiadó, 2010.

[12] Opauszki J.: Katasztrófa-egészségügyi képességek felmérése terrorcselekményből adódó tömeges sérültellátás tükrében. Diplomamunka, Budapest, Semmelweis Egyetem Egészségtudományi Kar, 2018.

[13] Pápai T.: A harctéri elsősegélynyújtás helye a hadszíntéri ellátásban és annak oktatás módszertani irányvonalai. Hadmérnök, 2011, 6(4): 111-113.

[14] Pápai D., Pápai T.: A fekvőbeteg ellátó intézmények valós idejü kiürítésének ápolói ismeretei és feladatai. Nővér, 2018, 31(2).

[15] Salomone, J., Pons, P., Giebner, S., Guy, J. (szerk.): Preshospital Trauma Life Support. Burlington: Jones \& Bartlett Learning, 2015.

[16] Svéd, L.: A Magyar Honvédség egészségügyi biztosítása elvének és gyakorlatának változásai, sajátosságai, különös tekintettel a haderő átalakításra, a NATO-ba történő integrálásra, a különböző fegyverek konfliktusok, valamint a békefenntartó, béketeremtő és -támogató tevékenységre. Doktori $(\mathrm{PhD})$ értekezés, Zrínyi Miklós Nemzetvédelmi Egyetem, Hadtudományi Doktori Iskola, 2003.

[17] Terrorism in Europe, 2018. https://en.wiki pedia.org/wiki/Terrorism_in_Europe

[18] Harctéri Egészségügyi Szakkiképzés, 2015. https://www.youtube.com/watch?v= YjGAPBtlZUU 
[19] Waxman, D. Chan, E. Pillemer, F. et al.: Assessing and improving hospital masscasualty preparedness: a no-notice exercise. Prehospital Disaster Medicine, 2017.

DOI: $10.1017 /$ S1049023X17006793

[20] Várhelyi: A robbanásos sérülések sebészi ellátásának kérdései. PhD értekezés, 2010. ZMNE Katonai Müszaki Doktor Iskola.

\section{Judit Opauszki}

\section{The aspects and possibilities of mass-casualty care in case of terrorist attacks involving mass shootings and bombings}

Terrorists - and islamist terrorists in particular - tend to prefer mass shootings and bombings: out of the total number of deaths due to terrorist attacks more than 70 percent can be attributed to gunfire and bombings and are accountable for around 65 percent of all casualties.
By monitoring and assessing the medical knowledge of randomly sampled soldiers of both the Hungarian Armed Forces and the paramedics of the emergency medical services from a catastrophe medicine perspective, I came to realize that training concerning gunfire and bombing casualties plays less significant role in their curriculum. This needs to be addressed through adapting combat experience and regular exercises.

Key-words: catastrophe medicine, terrorist attacks by guns and explosives, islamist terrorism, mass casualty exercise, improving preparedness, tourniquet.

Opauszki Judit 1134 Budapest, Róbert Károly krt. 44. 